IJTI (International Journal Of Transportation And Infrastruct ure)

\title{
CONTROL METHOD OF PALM OIL'S RAW MATERIALS SUPPLIES TO GUARANTEE THE QUALITY OF THE PRODUCT
}

\author{
Andira Puspita and Yuni Rahmawati \\ Narotama University, Surabaya, Indonesia \\ e-mail: andirapuspitaa@gmail.com , yunirahmawati95@gmail.com
}

\begin{abstract}
ABTRACT
The current economy has grown rapidly, along with the rapidly growing of Science and Technology (IPTEK). So the competition between companies becomes increasingly tight. The increasingly tight competition of the company encourages each company to determine the selection of raw material inventory appropriately so that the company can still exist in order to achieve its desired goals.

Keyword : Control Method, Palm Oils, Quality of Product
\end{abstract}

\section{INTRODUCTION}

Any company, whether a service company or a manufacturing company, always needs the inventory. In the absence of inventory, entrepreneurs will be exposed to the risk that his company at one time can not fulfill the wishes of its customers.

This may happen because the goods or services are not always available at all times, which means that the entrepreneur will lose the opportunity to earn the profit he or she should have. So inventory is very important for any company that produces both goods and services.

\section{Purpose of Paper}

The purpose of writing this paper is to know:

1. Understanding of raw material inventory control

2. Understanding the smoothness of the production process

3. Effect of raw material inventory control on the smoothness of production process

\section{LITERATURE REVIEW}

\section{Supply}

Understanding of Supply is all kinds of goods that become the main object of the company's activities which available for producted in the production process (Syakur: 2009). 


\section{a. Type of Supply}

According to Ristono (2009), based on it's purpose, the supply is divided into three types, namely as follows:

1. Safety supply (safety stock)

2. Anticipate Supply

3. On delivery supply (transit stock)

\section{b. Function Of Supply}

The supply functions according to Muslich (2009) are:

1. Meet the Orders

Storage of goods is required so that the company can fulfill the buyer's order in a short time. If the company does not have a stock of goods and can not fulfill the buyer's order at the right time, then probably the buyer will move to another company.

\section{Just in Case}

Just to guard if the goods on the market are difficult to obtain, except when the harvest arrives.

3. Suppress the main cost and production cost

To reduce the main cost of goods per unit by reducing the production costs perunit.

\section{Understanding the Production Process}

Most people interpret the production process is an activity to convert raw materials into intermediate goods or finished goods. But according to Syakur (2009) Production Process is a way, methods and techniques to create or increase the usefulness of a good or service by using sources (labor, machinery, materials and funds available). Thus, according to syakur, the production process is an activity that uses all of production factors in order to create an item that have value for use, or add the value for use of such goods.

\section{DISCUSSION}

\section{The Need for Raw Material Supplies}

The supply of raw materials in the company is a very reasonable thing to be well controlled. Any company that produces the product will need a supply of raw materials. Whether intentional or unintentional, both the company is a medium-sized company or a large corporation. However, the manner of this raw material inventory will be different for 
each company, whether in the number of raw material inventory unit in the company, or the management of the raw material inventory within the company concerned. Whatever the circumstances of a company, in principle all companies that carry out the production process will organize the raw material inventory for continuous implementation of production processes within the company. Some of the things that cause the company must conduct inventory of raw materials, among others, as follows:

a. The raw materials to be used for the implementation of the production process in the company, will not be purchased or imported one by one in the number of units required at the time when the material will be used for the production process of the company. Generally ,The raw materials will be purchased in a certain number of units, which will be used to support the implementation of production processes within the company for a certain period of time (eg, days, weeks, months etc.).

b. If the company do not have raw material inventory or if there is a condition that the necessary raw materials are not available, while the raw materials ordered to be imported into the company have not arrived, then the implementation of production process activities will be disrupted. Therefore, the absence of raw materials in this company will result the implementation of the production process was stopped, especially on machines and production equipment, that directly process the raw materials. In the next time the machines and production equipment used for the second, third and so on stages of the process will also be jammed because the first stage that directly process the material has no output.

c. To avoid this lack of raw materials, the management of the company may decide to provide raw material inventory in a considerable number of units. However, a large supply of raw materials in a company will bring a variety of consequences that will harm the company. The availability of raw materials held in large quantities will result in a large cost of material inventory.

2. Some Losses that will be Suffered by the Company In connection with the Implementation of Too Large Raw Material Inventories are:

a. The cost of storage or warehouse that responsibilited by the company becomes greater. The cost of storage must be incurred by the company is not just a warehouse leasing or warehouse maintenance alone, but will cover several other aspects.

b. Implementation of too large raw material inventory, will effect to prepare also a large enough fund to purchase materials. With the growing number of units of raw 
IJTI (International Journal Of Transportation And Infrastruct ure)

materials stored in the company means that the funds tied up in the investment of raw materials is becoming greater.

c. The high cost of storage within the company and the investment in the raw material inventory of the company will reduce the funds for financing and investment in other areas. In the other words, it can be mentioned that the too high number of raw material procurement units, will be a barrier of progress for the company.

\section{Some disadvantages if the Company Conducts Raw Materials Inventory in Small}

\section{Number of Units include:}

a. The small quantities supply of raw materials sometimes can not meet the needs of the company for the implementation of the production process.

b. If the company often run out of raw materials, then the implementation of the production process within the company can not run smoothly.

b. The average number of Raw materials inventory units in the company is relatively small. It will result the frequency of raw materials purchase will become greater.

By looking at some of the above weaknesses, it quite clear that all types of raw materials used for the implementation of the production process in the company, should be held the inventory, so that, the production process will not be disturbed because of run out of raw materials.

\section{CONCLUSION}

\section{Conclusion}

Based on the above discussion, the authors conclude that the implementation of raw material inventory, in this case was the control of raw materials, is very important for smooth production process. Due to the raw material is a very important element of production, the existence of raw material inventory including the control must be considered. It should not be excessive and diminish. Because, with the excess inventory of raw materials incurring a large cost which in this case will reduce the company's profit. Likewise, the less of raw materials supply will inhibit the production process, and it is also probably to cause the cost of purchasing materials will be enlarged. Because the purchase is not done normally, that is more expensive than the normal price.Thus, it will also incur greater costs and reduce company profits. 


\section{Suggestion}

In connection with the implementation of raw materials inventory, each of management company both large and small companies, should consider some of the things below so that the production process can run smoothly and the achievement of corporate goals. That is :

1. How many units of raw material inventory to be held within the company

2. When and how many units of raw materials to be purchased by the company.

\section{BIBLIOGRAPHY}

Syakur, Achmad, 2009, Intermediate Accounting, AV Publisher, Jakarta.

Artaya, I Putu., 2018, Dasar-Dasar Manajemen Operasi dan Produksi, Narotama University Press, Surabaya.

Artaya, I Putu., Arimbawa, I Gede, 2008, Penerapan Metode Korelasi dalam Mengukur Hubungan Antara Customer Relationship dengan Customer Loyalty Pada PT. Antika Raya Surabaya, Jurnal Bisnis dan Manajemen Universitas Negeri Surabaya. Vol. 1, No. 1.

Artaya, I Putu.,Kamisutara, Made., Baktiono, R Agus., 2018, Pengaruh Citra Produk Berdasarkan Analisis Persepsi Konsumen Pada Kelompok Usaha Aneka Pangan Di Sidoarjo, E-Jurnal Tata Sejuta STIA Mataram, Vol. 4, No. 1.

JFX Susanto S., Baktiono, R Agus, Artaya, I Putu., 2018, Optimization of governance model of post-food harest and distribution in msme centers in 5 subdistricts in sidoarjo regency, Journal of Economics, Business \& Accountancy Ventura, Vol. 20, No. 3.

Muslich. 2009. Metode Pengambilan Keputusan Kuantitatif. Bumi Aksara: Jakarta

Ristono, Agus. 2009. Manajemen persediaan. Yogyakarta: Graha IImu 